\title{
Antibodies to Bordetella pertussis adenylate cyclase are produced in man during pertussis infection and after vaccination
}

\author{
Z. FARFEL*, S. KÖNEN, E. WIERTZt, R. KLAPMUTSt, \\ P. A.-K. ADDY $¥$ and E. HANSKI
}

\begin{abstract}
Department of Hormone Research, The Weizmann Institute of Science, Rehovot 76100,* Department of Medicine E, Sheba Medical Center, Tel-Hashomer 51621 and Sackler School of Medicine, Tel Aviv University, Tel Aviv, Israel, +National Institute of Public Health and Environmental Protection, PO Box 1, 3720 BA, Bilthoven, The Netherlands and $¥ D$ epartment of Clinical Microbiology, University of Science and Technology, School of Medical Sciences, Kumasi, Ghana
\end{abstract}

\begin{abstract}
Summary. Bordetella pertussis produces several potential virulence factors. One of these is an adenylate cyclase which penetrates eukaryotic cells, is activated by calmodulin and generates high levels of intracellular cAMP. We have found that pertussis infection in man leads to production of high titres (2000-8000) of anti- $B$. pertussis adenylate cyclase antibodies. Such antibodies also are produced after pertussis vaccination. They persist into adulthood, cross the placenta and disappear a few months after birth. The anti-adenylate cyclase antibodies found in human serum during pertussis infection do not neutralise the catalytic and penetrative activities of the enzyme.
\end{abstract}

\section{Introduction}

Bordetella pertussis, the causative agent of whooping cough, produces several potential virulence factors that may play a role in the pathogenesis of the disease. ${ }^{1,2}$ The most studied and best characterised virulence factor is pertussis toxin (PT). PT causes many biological responses including lymphocytosis, histamine sensitisation and stimulation of insulin secretion, ${ }^{1,2}$ This toxin has recently been purified and shown to ADP-ribosylate several guanine-nucleotide binding proteins. ${ }^{3}$ ADP-ribosylation of $G_{i}$, the inhibitory guanine-nucleotide binding protein of the hormone-sensitive host adenylate cyclase $(\mathrm{AC})$ system, blocks receptormediated inhibition of $\mathrm{AC}$, thereby leading to increased intracellular cAMP levels. ${ }^{3}$ A role for PT in immunity to $B$. pertussis infection has been demonstrated both in animal models and in human disease. In mice, passive or active immunisation with PT induces protection from the disease produced by both intracerebral and aerosol challenges. ${ }^{4,5}$ Granström et al. ${ }^{6}$ demonstrated a rise in neutralising antibodies to PT in human sera after infection.

Received 7 Nov. 1989; revised version accepted 21 Dec. 1989. Correspondence should be sent to Dr E. Hanski, Department of Hormone Research, The Weizmann Institute of Science, Rehovot 76100, Israel.
Another toxin that dramatically affects host cAMP metabolism is $B$. pertussis AC. The location of the enzyme in the bacterial cell is mainly extracytoplasmic ${ }^{7,8}$ and its activity strongly depends on the eukaryotic calcium-binding protein calmodulin (CaM).$^{9}$ The enzyme penetrates eukaryotic cells and, upon activation by $\mathrm{CaM}$, produces high levels of intracellular cAMP. ${ }^{10,11}$ As a result, bactericidal functions of polymorphonuclear leucocytes and macrophages are impaired.,10 Thus, the enzyme may play an important role in the pathogenesis of the disease by inhibiting host defences. Weiss et al. ${ }^{12}$ showed, by transposon Tn5induced mutagenesis, that a $B$. pertussis strain deficient in AC was avirulent in an animal model of pertussis infection. Moreover, virulence for mice was restored when the mutant harboured a recombinant plasmid expressing AC activity. ${ }^{13}$ Recently, $B$. pertussis $\mathrm{AC}$ was purified, cloned and the genetic determinant sequenced. ${ }^{13-16}$ The availability of a purified preparation of $B$. pertussis $\mathrm{AC}$ has enabled us to test for the presence of anti-AC antibodies in patients with pertussis and in subjects after vaccination.

\section{Materials and methods}

\section{Patients and subjects}

Fifteen patients aged 6-61 (mean 23 SD 18) years with 
pertussis were included in the study. Although pertussis is mainly considered to be a disease of the very young, it has recently been observed more frequently in older children and adults. ${ }^{17}$ Two of the patients had not been vaccinated and in four patients the vaccination status was unknown. Serum was obtained by two of us (E.W. and R.K.) 15-100 (mean 37 SD 21) days after symptoms started. Diagnosis of pertussis in suspected cases was based on a high titre of IgG against PT ${ }^{18}$ Additionally all these subjects had a high titre of $\operatorname{IgA}$ antibodies against a whole-cell lysate of $B$. pertussis in comparison with a standard reference serum. ${ }^{19}$ These patients also showed PT-neutralising antibodies as determined by the Chinese hamster ovary (CHO) neutralisation test. ${ }^{6}$ Serum samples were also obtained from four neonates (cord blood), four unvaccinated infants 4-5 months old, four vaccinated children 2-3 years old, and four vaccinated adults 25-40 years old. IgG against PT and PTneutralising antibodies (CHO assay) were determined. The relevant patients and other subjects, including mothers of neonates, had been vaccinated with the wholecell vaccine in childhood. The four vaccinated children were immunised three times during their first year of life, and given a booster-dose a year later. None of the control subjects had had clinical pertussis.

\section{Purification of $B$. pertussis $A C$}

Purified preparations of $B$. pertussis AC were obtained from a wild type $B$. pertussis strain and from a cloned Escherichia coli strain expressing the enzyme. $B$. pertussis strain 165 was grown and harvested as described previously. ${ }^{11}$ The $200-\mathrm{Kda}$ form of the enzyme was purified according to the procedure of Rogel et al. ${ }^{15}$ This form of the enzyme was chosen because it represents the product of the entire $B$. pertussis AC gene. ${ }^{16,20}$

A gene library of $B$. pertussis was constructed from chromosomal DNA of strain Tabl by Brownlie et al. ${ }^{13} \mathrm{~A}$ 10-kb DNA fragment, containing the structural gene of $B$. pertussis AC and two out of three genes required for $\mathrm{AC}$ secretion, ${ }^{21}$ was subcloned into the vector pIC20H to give the plasmid pRMB3. This plasmid was transformed into E. coli H1469 Loñ strain and the enzyme produced was purified as described previously. ${ }^{22}$

\section{Immunoblotting}

Purified 200-Kda form of the enzyme at a concentration of $0.5-1 \mu \mathrm{g} /$ lane was subjected to polyacrylamide gel electrophoresis in the presence of sodium dodecyl sulphate (SDS-PAGE) and then electrophoretically transferred to nitrocellulose in a buffer containing $15.6 \mathrm{mM}$ Tris- $\mathrm{HCl}$ and $120 \mathrm{~mm}$ glycine at $\mathrm{pH} 8 \cdot 3$. The transfer was conducted for $2 \mathrm{~h}$ at $190 \mathrm{~mA}$. The nitrocellulose was cut into individual strips, blocked for $30 \mathrm{~min}$ with phosphatebuffered saline (PBS) containing bovine serum albumin (BSA) $2 \% \mathrm{w} / \mathrm{v}$ and then incubated overnight at $4{ }^{\circ} \mathrm{C}$ with dilutions of various sera, in a final volume of $10 \mathrm{ml}$. The incubation solution contained PBS supplemented with BSA $2 \% \mathrm{w} / \mathrm{v}$. The strips were then washed four times, each for $10 \mathrm{~min}$, with the following solutions: (1) PBS, (2 and 3) PBS containing Tween $200.2 \% \mathrm{w} / \mathrm{v}$, and (4) PBS. The nitrocellulose strips were then incubated for $2 \mathrm{~h}$ at room temperature in PBS containing BSA $2 \%$ w/v which was supplemented with ${ }^{125}$ I-labelled protein $\mathrm{A} 10^{5} \mathrm{cpm} /$ $\mathrm{ml}$. Unbound protein A was removed by repeated washing with PBS containing Tween $200.2 \%$ w/v. The strips were dried and autoradiographed at $-70^{\circ} \mathrm{C}$ for $14 \mathrm{~h}$.

\section{Inhibition of $A C$ activity}

$\mathrm{AC}$ activity was determined in a total volume of $50 \mu \mathrm{l}$ as described previously. ${ }^{11}$ The ability of the various sera to inhibit AC activity was assessed as follows: $20-\mu 1$ volumes of undiluted sera, and of sera diluted 1 in 10 and 1 in 100 in PBS supplemented with BSA $1 \%$ w/v, were incubated for $4 \mathrm{~h}$ at $4^{\circ} \mathrm{C}$ with $20 \mu \mathrm{l}$ of the $200-\mathrm{Kda}$ form of the enzyme purified from $B$. pertussis, at an activity of $8 \mathrm{nmol}$ of $\mathrm{cAMP} / \mathrm{min} / \mathrm{ml}$. At the end of the incubation period, three samples, each of $10 \mu \mathrm{l}$, were withdrawn and assayed for AC activity. As a control we used neutralising anti-B. pertussis AC serum. ${ }^{15}$ This serum was obtained from only one guinea-pig out of six immunised with purified $B$. pertussis $A C$; the rest of the animals produced non-neutralising anti- $B$. pertussis AC antibodies (E. Hanski, unpublished observation). This neutralising serum completely inhibited the AC activity of the 200$\mathrm{Kda}$ form of the enzyme at dilutions up to 1 in $200 .{ }^{15}$

\section{Inhibition of penetrative activity}

Penetrative activity was determined by measurement of intracellular cAMP accumulation as described previously. ${ }^{11}$ Human lymphocytes were used as target cells for the enzyme. The invasive form of $B$. pertussis $\mathrm{AC}$ was isolated by gel filtration of a crude bacterial extract. ${ }^{15}$ The specific activity of this preparation was $3.1 \mu \mathrm{mol}$ of $\mathrm{cAMP} / \mathrm{min} / \mathrm{mg}$ protein and its capacity for penetration was $0.35 \mu \mathrm{mol}$ of cAMP $/ \mathrm{mg}$ of lymphocyte protein $/ \mathrm{mg}$ of bacterial protein. The invasive enzyme $(40 \mu \mathrm{l})$ was incubated with the various sera $(40 \mu \mathrm{l}$ of undiluted serum or serum diluted 1 in 10 or 1 in 100 in PBS supplemented with BSA $0 \cdot 1 \% \mathrm{w} / \mathrm{v}$ ) for $5 \mathrm{~h}$ at $4^{\circ} \mathrm{C}$ before testing. Then, three 20- $\mu$ l samples were withdrawn and the penetrative activity was determined. In control experiments the neutralising anti- $B$. pertussis AC serum completely blocked the entry of the invasive form of enzyme at dilutions of up to 1 in 200.

\section{Results}

We tested human sera for the presence of anti-B. pertussis AC antibodies. High amounts of anti-AC antibodies were detected in all patients with pertussis (table I). In contrast, anti-AC antibodies could not be detected in sera from healthy nonvaccinated infants as shown for one of them in fig. 1. The patients' sera used in this study contained $\operatorname{Ig} A$ antibodies against a whole-cell lysate of $B$. 
Table I. Anti-B. pertussis AC antibody titres in various groups

\begin{tabular}{lcc}
\hline \multicolumn{1}{c}{ Group } & $\begin{array}{c}\text { Number } \\
\text { of subjects }\end{array}$ & Titre* \\
\hline Pertussis patients & 15 & $2000-8000$ \\
Neonates & 4 & $100-300$ \\
Non-vaccinated infants & 4 & Not detected \\
Vaccinated children & 4 & $200-800$ \\
Vaccinated adults & 4 & $200-600$
\end{tabular}

* The presence of anti- $B$. pertussis AC antibodies was assessed by immunoblotting. The titre indicates the maximum serum dilution which could specifically detect the $200-\mathrm{Kda}$ form of $B$. pertussis AC according to the conditions described in Materials and methods.

pertussis at titres with a relative potency index of $>$ 5 , as determined by the method of Nagel and PootScholtens. ${ }^{19}$ The anti-PT IgG and CHO-neutralising antibody titres of different donor groups are shown in table II. There was no difference between the titres of vaccinated and non-vaccinated patients. In non-vaccinated infants, anti-PT antibodies were hardly detected, whereas in neonates $\mathrm{CHO}$ neutralising antibodies were detected in higher titres. In vaccinated children, CHO-neutral-

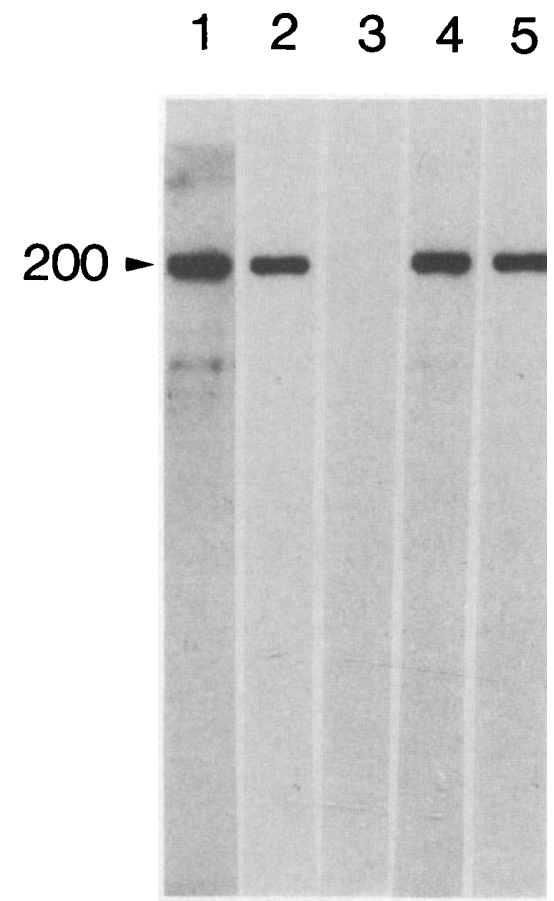

Fig. 1. Immunoblotting of $B$. pertussis $\mathrm{AC}$, with human sera from: (1) pertussis patient, diluted 1 in 1000 ; (2) neonate, 1 in $100 ;(3)$ non-vaccinated infant, 1 in $50 ;(4)$ vaccinated child, 1 in $300 ;(5)$ vaccinated adult, 1 in 300. ising titres were even higher, approaching those detected during pertussis infection. Table I shows the titres of anti-B. pertussis AC antibodies in the various groups studied. Very high titres $(2000$ 8000 ) were found in patients with pertussis, irrespective of their vaccination status. In contrast, in non-vaccinated infants 4-5 months old, no such antibodies could be detected even at a dilution of 1 in 20 (table I; fig. 1). However, anti-B. pertussis AC antibodies could be detected in cord blood and in vaccinated children and adults.

To exclude the possibility that a minor contaminant of the AC preparation, of similar molecular weight, was responsible for the interactions on the Western blots, the control experiment shown in fig. 2 was performed. $B$. pertussis AC was purified from an $E$. coli strain harbouring a plasmid that encodes for the structural gene of $B$. pertussis AC. ${ }^{13,21}$ All patients' sera interacted with the enzyme produced in $E$. coli, as shown for one patient in fig. 2. This interaction was specific since recognition of the enzyme was not detected with serum from a nonvaccinated infant.

The ability of sera from pertussis patients to neutralise $B$. pertussis AC activity was examined by two assays: inhibition of enzymic activity and inhibition of penetration of the enzyme into target cells. None of the human sera examined showed such properties. In animals (rabbits and guineapigs) immunised with purified $B$. pertussis AC, high titres of anti- $B$. pertussis AC were detected by immunoblotting. ${ }^{14,15}$ However, neutralisation of enzymic activity and penetrative ability of $B$. pertussis AC was found in the serum of only one guinea-pig out of six immunised. This serum completely inhibited both activities at a dilution of 1 in $200 .{ }^{15}$

\section{Discussion}

This study demonstrates the capacity for production of antibodies against $B$. pertussis $\mathrm{AC}$ in man and is the first direct evidence that $\mathrm{AC}$ is produced by $B$. pertussis during infection. The anti-AC antibodies are produced in high titres after infection. These antibodies are also produced after vaccination, persist into adulthood, cross the placenta and disappear a few months after birth. It appears that higher titres of anti-AC antibodies are produced after infection than after vaccination, although this may be due to differences in the timing of the observations. Further studies are required to substantiate this finding. Recently, it has been reported that anti-filamentous haemagglutinin (FHA) antibodies appear in sera of pertussis 
Table II. Anti-pertussis toxin antibody titres in various groups

\begin{tabular}{lcll}
\hline \multicolumn{1}{c}{ Group } & $\begin{array}{c}\text { Number } \\
\text { of subjects }\end{array}$ & $\begin{array}{l}\text { IgG } \\
\text { titre }\end{array}$ & $\begin{array}{l}\text { CHO-neutralising } \\
\text { antibody titre }\end{array}$ \\
\hline Pertussis patients & 15 & $\begin{array}{l}\text { Range } 1600-25600 \\
\text { Median } 3200-6400\end{array}$ & $\begin{array}{l}\text { Range } 20-640 \\
\text { Median } 160-320\end{array}$ \\
$\begin{array}{l}\text { Neonates } \\
\text { Non-vaccinated infants }\end{array}$ & 4 & $<50,<50,<50,100$ & $\begin{array}{l}1,4,4,8 \\
\text { Vaccinated children }\end{array}$ \\
\hline
\end{tabular}

*See Materials and methods for anti-PT IgG and CHO-neutralising antibody assays.

patients $^{23}$. Since FHA has a molecular weight of $210-220 \mathrm{Kda},{ }^{23}$ it could have contaminated the preparations of the $200-\mathrm{Kda}$ form of $\mathrm{AC}$, purified from the wild type $B$. pertussis strain. To exclude this possibility, B. pertussis AC cloned in $E$. coli was utilised and showed the same response as observed for the enzyme purified from the native $B$. pertussis cells.

$B$. pertussis AC antibodies could be detected by immunoblotting with protein $\mathrm{A}$, which detects human IgG. These antibodies did not neutralise the enzymic activity or penetrative ability of the

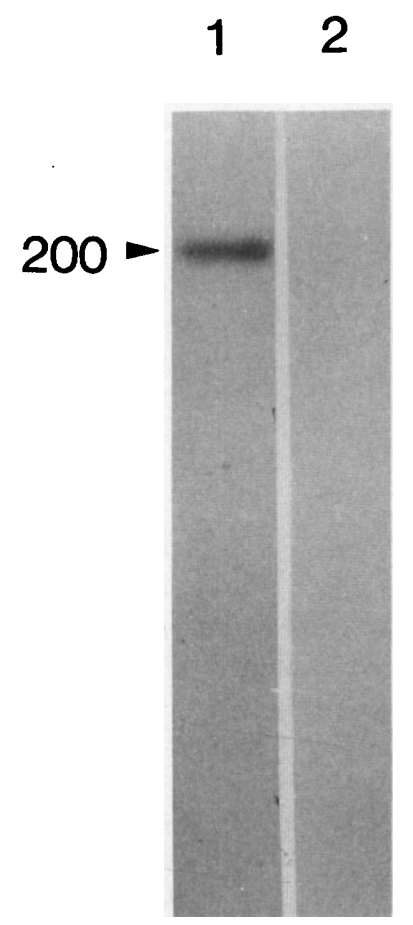

Fig. 2. B. pertussis AC expressed in $E$. coli is specifically recognised in an immunoblot by serum from a pertussis patient. Lane 1 shows the reaction with serum from a pertussis patient, diluted 1 in 4000 ; lane 2 , reaction with serum from a nonvaccinated infant diluted 1 in 50 . enzyme but the lack of neutralising capacity does not indicate that these antibodies are insignificant for host immunity. Brezin et al. ${ }^{24}$ showed that both AC enzymic-activity-neutralising and non-neutralising antibodies prevented the lethal effects of the haemorrhagic alveolitis in mice infected with $B$. pertussis. It is possible that, during infection, there is production of different local antibodies that can neutralise the activities of $B$. pertussis AC. Alternatively, locally produced antibodies, which are similar to those detected by us in the serum, may be important for defence against the $\mathrm{AC}$ toxin in the respiratory tract. AC toxin, either secreted by the bacteria ${ }^{25}$ or extracted from them, ${ }^{10,11}$ penetrates various eukaryotic cells. Its mechanism of penetration into respiratory tract cells during infection is not known. Hewlett et al. ${ }^{26}$ suggested that a direct contact between bacteria and target cells is required for intoxication with $B$. pertussis AC. During infection, locally produced antibodies similar to those detected by us in human sera may interfere with the penetration of the invasive enzyme via direct contact. Recently, Raptis et al. ${ }^{27}$ reported that hyperimmune human sera could neutralise $B$. pertussis AC activity but details were not provided. The apparent discrepancy between these results and ours is as yet not understood.

In the case of PT, the appearance of neutralising antibodies has been considered to be further evidence for its role in virulence. Granström et al. ${ }^{6}$ claimed that PT-neutralising antibodies are important for long term immunity against pertussis. However, some of the patients reported in their study, in spite of having initial high titres of PTneutralising antibodies, developed pertussis. Furthermore, Trollfors et al..$^{28} \mathrm{did}$ not find a correlation between anti-PT IgG and CHO-neutralising antibodies during pertussis infection. In some of their patients, CHO-neutralising antibodies were not detected. However, it was not reported whether or not the course of the disease in these patients was more severe than in the other patients. 
The use of $B$. pertussis AC for diagnosis of pertussis was described by Confer and Eaton. ${ }^{29}$ Nasopharyngeal swabs, carrying as few as $100 \mathrm{~B}$. pertussis organisms, induced detectable levels of cAMP. The observation that anti-AC antibodies are produced during pertussis infection in titres apparently higher than those appearing after

\section{REFERENCES}

1. Weiss AA, Hewlett EL. Virulence factors of Bordetella pertussis. Ann Rev Microbiol 1986; 40: 661-686.

2. Friedman RL. Pertussis: The disease and new diagnostic methods. Clin Microbiol Rev 1988; 1 : 365-376.

3. Ui $\mathbf{M}$, Nogimori $\mathbf{K}$, Tamura $\mathbf{M}$. Islet-activating protein, pertussis toxin, subunit structure and mechanism for its multiple biological actions. In: Sekura RD, Moss J, Vaughan M (eds) Pertussis toxin. Orlando, Academic Press. 1985; 19-43.

4. Sato Y, Izumiya K, Sato H, Cowell JL, Manclark CR. Role of antibody to leukocytosis-promoting factor hemagglutinin and to filamentous hemagglutinin in immunity to pertussis. Infect Immun $1981 ; 31$ : 12231231.

5. Sato H, Sato Y. Bordetella pertussis infection in mice: Correlation of specific antibodies against two antigens, pertussis toxin and filamentous hemagglutinin with mouse protectivity in an intracerebral or in aerosol challenge system. Infect Immun 1984; 46: 415-421.

6. Granström $M$, Granström $G$, Gillenius $P$, Askelöf $P$. Neutralizing antibodies to pertussis toxin in whooping cough. J Infect Dis 1985; 151 : 646-649.

7. Hewlett EL, Urban MA, Manclark CR, Wolff J. Extracytoplasmic adenylate cyclase of Bordetella pertussis. Proc Natl Acad Sci USA 1976; 73: 1926-1930.

8. Masure HR, Storm DR. Characterization of the bacterial cell associated calmodulin-sensitive adenylate cyclase of Bordetella pertussis. Biochemistry 1989; $28: 438-442$.

9. Wolff J, Cook GH, Goldhammer AR, Berkowitz SA. Calmodulin activates prokaryotic adenylate cyclase. Proc. Natl Acad Sci USA 1980; 77: 3841-3844.

10. Confer DL, Eaton JW. Phagocytic impotence caused by an invasive bacterial adenylate cyclase. Science 1982 ; 217: 948-950.

11. Hanski E, Farfel Z. Bordetella pertussis invasive adenylate cyclase: Partial resolution and properties of its cellular penetration. J Biol Chem 1985: 260: 5526-5532.

12. Weiss AA, Hewlett EL, Myers GA, Falkow S. Tn5-induced mutations affecting virulence factors of Bordetella pertussis. Infect Immun 1983; 42: 33-41.

13. Brownlie RM, Coote JG, Parton R, Schultz JE, Rogel A, Hanski E. Cloning of the adenylate cyclase genetic determinant of Bordetella pertussis and its expression in Escherichia coli and B. pertussis. Microb Pathog 1988; 4: 335-344.

14. Ladant D, Brezin C, Alonso JM, Crenon I, Guiso N. Bordetella pertussis adenylate cyclase: purification, characterization and radioimmunoassay. $J$ Biol Chem 1986; 261 : 16264-16269.

15. Rogel A, Farfel Z, Goldschmidt S, Shiloach J, Hanski E. vaccination may form a basis for their use as an additional tool for diagnosis of pertussis.

We thank Mrs Rona Levin for efficient processing of this manuscript. This research was supported by a grant from the US-Israel Co-operative Development Research Program to E.H. and to P.A.-K.A.

Bordetella pertussis adenylate cyclase: Identification of multiple forms of the enzyme by antibodies. J. Biol Chem 1988; 263: 13310-13316.

16. Glaser P, Ladant D, Sezer O, Pichot F, Ullmann A, Danchin A. The calmodulin-sensitive adenylate cyclase of Bordetella pertussis. Cloning and expression in Escherichia coli. Mol Microbiol 1988; 2: 19-30.

17. Linnemann CC, Nasenbeny J. Pertussis in the adult. Annu Rev Med 1977; 28 : 179-185.

18. Nagel J, de Graaf S, Schijf-Evers D. Improved serodiagnosis of whooping cough caused by Bordetella pertussis by determination of IgG anti-LPF antibody levels. Dev Biol Stand 1985; 61 : 325-330.

19. Nagel J, Poot-Scholtens EJ. Serum IgA antibodies to Bordetella pertussis as an indicator to infection. J. Med Microbiol 1983; 16: 417-426.

20. Hanski E. Invasive adenylate cyclase toxin of Bordetella pertussis. Trends Biochem Sci 1989; 14 : 459-463.

21. Glaser P, Sakamoto H, Bellalou J, Ullmann A, Danchin A. Secretion of cyclolysin, the calmodulin-sensitive adenylate cyclase-haemolysin bifunctional protein of Bordetella pertussis. Embo J 1988; 7: 3997-4004.

22. Rogel A, Schultz JE, Brownlie RM, Coote JG, Parton R, Hanski E. Bordetella pertussis adenylate cyclase: Purification and characterization of the toxic form of the enzyme. EMBO J 1989; 8: 2755-2760.

23. Redd, SC, Rumschlag HS, Biellik RJ, Sanden GN, Reimer $\mathrm{CB}$, Cohen ML. Immunoblot analysis of humoral immune responses following infection with Bordetella pertussis or immunization with diphtheria-tetanuspertussis vaccine. J Clin Microbiol 1988; 26: 1373-1377.

24. Brezin C, Guiso N, Ladant D, Djavadi-Ohaniance L, Megret F, Onyeocha I, Alonso JM. Protective effect of anti-Bordetella pertussis adenylate cyclase antibodies against lethal respiratory infection of the mouse. FEMS Microbiol Lett $1987 ;$ 42: 75-80.

25. Masure HR, Shattuck RL, Storm DR. Mechanisms of bacterial pathogenicity that involve production of calmodulin-sensitive adenylate cyclases. Microbiol Rev $1987 ; 51: 60-65$.

26. Hewlett EL, Gray MC, Pearson RD. Delivery of Bordetella pertussis adenylate cyclase toxin to target cells by intact bacteria. Clin Res $1987 ; 35: 477$ a.

27. Raptis A, Knipling L, Wolff J. Dissociation of catalytic and invasive activities of Bordetella pertussis adenylate cyclase. Infect Immun 1989; 57: 1725-1730.

28. Trollfors B, Krantz I, Sigurs N, Taranger J, Zackrisson G, Roberson R. Toxin-neutralizing antibodies in patients with pertussis, as determined by an assay using Chinese hamster ovary cells. J. Infect Dis 1988; 158: 991-995.

29. Confer DL, Eaton JW. Bordetella adenylate cyclase: host toxicity and diagnostic utility. Dev Biol Stand 1985; 61 : 3-10. 